\title{
Economic impact of pharmaceutical interventions on healthcare services from Brazil: a systematic review
}

\author{
Gustavo Baldin TIGUMAN ${ }^{1}$ (D), Ronaldo Morales JUNIOR² \\ ${ }^{1}$ Faculdade de Ciências Farmacêuticas, ${ }^{2}$ Hospital Sírio Libanês, São Paulo, Brasil \\ Corresponding Author: Tiguman GB, gustavo.tiguman@gmail.com \\ Submitted: 27-07-2020 Resubmitted: 11-10-2020 Accepted: 11-10-2020 \\ Peer review: blind reviewer and André de Oliveira Baldoni
}

\begin{abstract}
Objective: The aim of this research was to systematically review the studies that investigated the economic impact of the pharmaceutical intervention in Brazilian healthcare services. Methods: A systematic search was conducted in the MEDLINE, EMBASE, and LILACS databases to select the economic evaluations published until November 2019. Two independent authors selected the studies, extracted the data, and assessed the methodological quality using the 19-items Consensus on Health Economic Criteria (CHEC-list) instrument and the reporting quality using the 24-items Consolidated Standards of Economic Health Assessment (CHEERS) checklist. Results: Out of the 290 identified articles, 10 met the eligibility criteria. Most studies were conducted in the southeastern region of Brazil ( $n=7)$ and significantly differed in design, economic outcome measure, and type of intervention. The majority $(n=8)$ reported that pharmaceutical practice resulted in reduction of costs and clinical benefits to patients. In general, the methodological and the reporting qualities of the studies were low/moderate with an average score at CHEC-list of 10.3 (range: 3-16 points) and at CHEERS of 15.8 (range: $11-21$ points). Conclusions: The Brazilian studies indicate that the pharmacist intervention can lead to economic and clinical benefits for healthcare services. The methodological and the reporting qualities of the studies were limiting factors.
\end{abstract}

Keywords: systematic review, pharmaceutical services, pharmacist, technology assessment, biomedical, Brazil, economics, pharmaceutical.

\section{Impacto econômico da intervenção farmacêutica em serviços de saúde do Brasil: uma revisão sistemática}

\section{Resumo}

Objetivo: O objetivo desta pesquisa foi revisar sistematicamente estudos que investigaram o impacto econômico da intervenção farmacêutica em serviços de saúde brasileiros. Métodos: Uma pesquisa sistemática foi conduzida nas bases de dados MEDLINE, EMBASE e LILACS para selecionar as avaliações econômicas publicadas até novembro de 2019. Dois autores independentes selecionaram os estudos, extraíram os dados e avaliaram a qualidade metodológica usando a ferramenta Consensus on Health Economic Criteria (CHEC-list) de 19 itens e a qualidade de reporte usando o checklist Consolidated Health Economic Evaluation Reporting Standards (CHEERS) de 24 itens. Resultados: Dos 290 artigos identificados, 10 atingiram os critérios de elegibilidade. A maioria dos estudos foi conduzida na região Sudeste do Brasil $(n=7)$ e diferiram significativamente quanto ao delineamento, à medida de avaliação econômica e ao tipo de intervenção. A maior parte $(n=8)$ reportou que a atuação do farmacêutico gerou economias importantes às instituições de saúde, além de proporcionar benefícios clínicos aos pacientes. No geral, a qualidade metodológica e de reporte dos estudos foi baixa/ moderada, com uma média de pontuações no CHEC-list de 10,3 (intervalo: 3-16 pontos) e no CHEERS de 15,8 (intervalo: 10-21 pontos). Conclusões: Os estudos brasileiros indicam que a intervenção farmacêutica gera possíveis benefícios econômicos e clínicos aos serviços de saúde. A qualidade metodológica e de reporte dos estudos foi um fator limitante.

Palavras-chave: revisão sistemática, assistência farmacêutica, farmacêuticos, avaliação da tecnologia biomédica, Brasil, farmacoeconomia. 


\section{Introduction}

Adverse drug events can result in important health problems to patients, with significant clinical and economic impacts. ${ }^{1}$ Pharmacists are health professionals increasingly inserted in multidisciplinary teams due to their wide range of activities related to pharmacotherapy, which include medication review, medication reconciliation, elaboration of clinical protocols, and promotion of the rational use of medicines, among others..$^{2-5}$

Pharmaceutical interventions are "planned and documented acts performed with the patients and health professionals, which aim to solve or prevent problems related to pharmacotherapy and ensure the achievement of therapeutic goals". ${ }^{6}$ A previous systematic review evaluated the impact of the clinical activity of pharmacists in Brazil, reporting positive results for the patients. ${ }^{7}$

Brazil is the only capitalist country in Latin America to adopt a universal health system - the Unified Health System (Sistema Único de Saúde, SUS) - since 1988, which guarantees universal access to health services by the population. ${ }^{9}$ Since 2016, however, the country faces a political-economic crisis, which resulted in the implementation of austerity policies that also involve budget reductions in the health area. ${ }^{10-13}$ Research studies related to the optimization of resources and the reduction of health costs are imperative in the current Brazilian context.

In developed countries, such as the United States, it is suggested that the role of the pharmacist in optimizing clinical outcomes potentially generates economic effects, resulting in savings for health services. ${ }^{8}$ However, no review on the economic impact of this professional in Brazilian health services has been published so far.

This systematic review aims to investigate the economic impact of the pharmaceutical intervention in Brazil and to assess the methodological and reporting qualities of primary studies conducted in the country.

\section{Methods}

The protocol of this systematic review was published on the PROSPERO platform (registration number: CRD42020165028) without prior evaluation for registration, since the platform is currently evaluating only studies related to Covid-19. This systematic review adhered to the reporting recommendations of the Preferred Reporting Items for Systematic Reviews and Meta-Analyses (PRISMA). ${ }^{14}$ The research question was the following: "What is the economic impact of the pharmacist intervention on the treatment of patients in health services in Brazil?"

\section{Eligibility criteria}

The eligibility criteria to answer the research question was elaborated based on the PICO structure (patients, intervention, comparator, outcome). The full articles published in journals that assessed the economic impact of the pharmaceutical intervention, when compared to non-intervention, on patients treated in Brazilian health services were considered eligible for inclusion in this systematic review. No restrictions related to the study design, publication period or language were applied, since this research sought to analyze the results of all published articles that could potentially answer the research question, including randomized clinical trials and observational studies (case-control and cohort). In this study, observational studies were eligible due to the potential limitation of the number of randomized clinical trials available on the topic. Systematic reviews, meta-analyses, overviews and conference abstracts were not considered.

\section{Participants}

This systematic review included patients of all ages treated in Brazilian health services by pharmacists. Studies that evaluated the impact of the pharmaceutical practice on patients treated in countries other than Brazil were excluded from the analysis.

\section{Intervention}

"Pharmaceutical intervention" was defined as any action taken by the pharmacist professional in order to change the process of medication use, both with regard to the patient and to other health professionals ${ }^{15}$, including the review of prescriptions, medication reconciliation, elaboration of clinical protocols, promotion of the rational use of medications through pharmaceutical care, and management of antimicrobials, among others.

\section{Comparator}

In this systematic review, the comparator was defined as the non-intervention of the pharmacist in Brazilian health services.

\section{Outcomes}

The primary outcome was defined as the cost reduction resulting from the pharmaceutical intervention. Due to the great variability in the measurement of cost reductions, the primary outcome was presented as the difference in direct costs (such as costs of appointments with health professionals, laboratory tests, emergency visits, hospitalization and drug treatments, among others) and indirect costs (transportation of patients to the health services, costs related to absenteeism at work, etc.), the Cost-Effectiveness Ratio (CER) or the Incremental Cost-Effectiveness Ratio (ICER). The secondary outcomes included the clinical impacts of the professionals' work, such as the reduction of problems related to pharmacotherapy, greater adherence to treatment, improvements in the levels of disease markers, and decreased consumption of medications.

\section{Information sources}

A bibliographic search was carried out on November 25 th 2019 in the following databases: MEDLINE (via PubMed), EMBASE, and Latin American and Caribbean Health Sciences Literature (LILACS). The search strategies for each database are described in Supplementary Material 1.

\section{Selection of studies}

The selection of studies was carried out by both authors independently and considering the eligibility criteria through the evaluation of titles and abstracts. The pre-selected studies were evaluated in full-text to ensure that the criteria was met. Disagreements in the selection of articles were resolved by consensus. 


\section{Data extraction}

The data of the selected studies were individually extracted by both authors using a Microsoft Excel spreadsheet developed for this research, which included the following information: name of the first author, year of publication, Brazilian state (location where the study was conducted), study design (randomized clinical trial or observational study), number of patients, target population (disease or specific condition), time horizon (months), funding agency, type of pharmaceutical intervention (as reported in the primary studies), economic outcomes measures (direct and/or indirect costs, CER or ICER), economic outcomes results, clinical outcomes measures (reduction of problems related to pharmacotherapy, adherence to treatment, etc.), and clinical outcomes results.

\section{Evaluation of the quality of the studies}

The evaluation of the methodological quality of the economic studies was conducted by both authors independently using the Consensus on Health Economic Criteria (CHEC-list) tool. ${ }^{16}$ The CHEC-list is an instrument widely used in systematic reviews of economic studies, 17 with 19 questions whose answer options are "yes" (compliant) and "no" (non-compliant). According to the proportion of questions with "yes" answers among the 19 questions of the instrument, the studies were classified as high quality (score $\geq 75 \%$ ), medium quality (score between $51 \%$ and $74 \%$ ) and low quality (score $\leq 50 \%){ }^{18}$

The reporting quality of the economic studies included was independently analyzed by both authors using the Consolidated Health Economic Evaluation Reporting Standards (CHEERS) checklist. ${ }^{19}$ This document includes six areas: (i) title and abstract (2 items); (ii) introduction (1 item); (iii) methods (14 items); (iv) results (4 items); and (v) discussion (1 item). The items were classified as "yes" (completely reported), "no" (not reported or partially reported) and "not applicable". The analyses followed the detailed recommendations of the ISPOR Health Economic Evaluation Publication Guidelines Good Reporting Practices Task Force $^{20}$ for each item. The total score was obtained by assigning one point for each "yes" answer and zero points for all other answers, ranging from 0 to 24 points.

\section{Synthesis of the results}

The results extracted from the studies were synthesized based on economic and clinical outcomes. Individual qualitative analyses were made in terms of cost reduction and clinical impacts resulting from the pharmaceutical intervention. The heterogeneity between the economic outcomes evaluated in the studies made it impossible to conduct a meta-analysis.

\section{Results}

\section{Selection of studies}

In total, 290 potentially relevant articles were identified by searching the databases. Of these, 29 were duplicates (present in more than one database). After reviewing the titles and abstracts of the remaining 261 studies, 246 were excluded for not evaluating the impact of the pharmaceutical intervention. The remaining 15 articles were selected for full-text reading, of which 10 met the eligibility criteria and were included in this systematic review. The process of study selection according to the inclusion and exclusion criteria is shown in Figure 1.
Figure 1. Flow diagram of the selection of the studies after searching the databases.

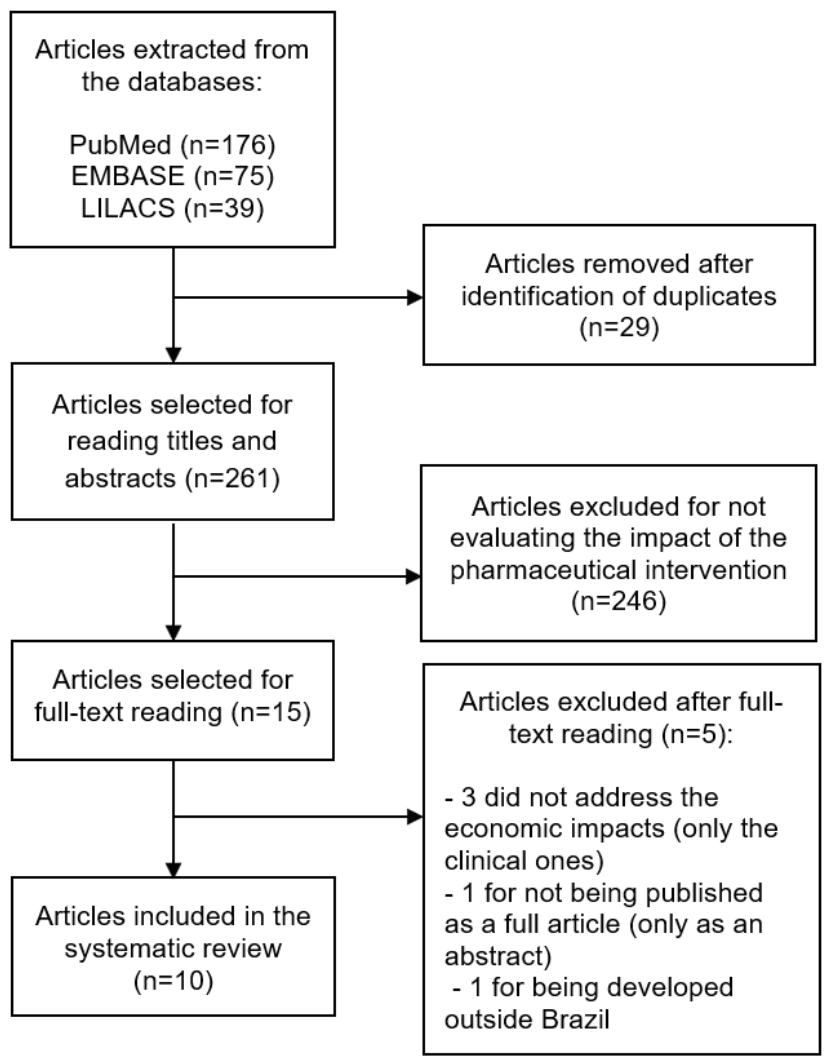

\section{Characteristics of the studies}

The characteristics of the 10 studies included in this review are described in Table 1. Most studies were conducted in the Brazilian Southeast region $(n=7)$. Prospective observational studies $(n=3)$, quasi-experimental studies $(n=2)$, randomized clinical trials $(n=2)$, ambispective studies $(n=1)$, retrospective observational studies $(n=1)$ and case studies $(n=1)$ were included. Most of the studies evaluated patients with type 2 diabetes mellitus and cardiovascular diseases $(n=5)$ and reported a time horizon of 12 months or more $(n=9)$. Only 4 studies were funded, all by research funding agencies.

\section{Results of the economic evaluations}

The main results of the economic evaluations are summarized in Table 2. Thetypes of intervention were describedas: pharmaceutical care $(P C)(n=4)$, pharmacotherapeutic empowerment strategy $(n=1)$, clinical pharmacist interventions $(n=1)$, prescription review $(n=1)$, method of disease self-management $(n=1)$, pharmaceutical audit $(n=1)$ and participation in an antimicrobial stewardship program $(n=1)$. The studies conducted analyses of direct costs $(n=7)$, CER/ICER $(n=1)$, direct, indirect costs and CER/ICER $(n=1)$ and direct costs and ICER per Quality-Adjusted Life-Year (QALY) $(n=1)$. In general, the pharmaceutical interventions resulted in a statistically significant cost reduction in relation to the control groups $(n=8)$. In two studies, the pharmacist practice did not result in a statistical difference in financial terms; both, however, reported significant clinical improvements, mainly related to the reduction of problems related to pharmacotherapy and beneficial changes in the levels of disease markers. ${ }^{21,22}$ 
Table 1. Characteristics of the studies evaluating the economic impact of the pharmaceutical intervention on Brazilian health services.

\begin{tabular}{|c|c|c|c|c|c|c|c|c|}
\hline Citation & $\begin{array}{l}\text { Location } \\
\text { (State) }\end{array}$ & Study design & $\begin{array}{l}\text { Number of } \\
\text { patients }\end{array}$ & Target population & $\begin{array}{l}\text { Time horizon } \\
\text { (months) }\end{array}$ & Funding & $\begin{array}{l}\text { CHEC-list score } \\
\text { (Total=19) }\end{array}$ & $\begin{array}{l}\text { CHEERS score } \\
\text { (Total }=24)\end{array}$ \\
\hline $\begin{array}{l}\text { Gonçalves ACO } \\
\text { et al. }(2019)^{23}\end{array}$ & $\begin{array}{l}\text { Minas } \\
\text { Gerais }\end{array}$ & $\begin{array}{l}\text { Retrospective } \\
\text { observational }\end{array}$ & 107 & $\begin{array}{l}\text { Patients with type } 2 \\
\text { diabetes mellitus }\end{array}$ & 12 & None & $\begin{array}{l}15 \text { (78.9\%) } \\
\text { High Quality }\end{array}$ & 19 \\
\hline $\begin{array}{l}\text { Cazarim MS } \\
\text { and Pereira LRL. } \\
(2018)^{24}\end{array}$ & São Paulo & Quasi-experimental & 104 & $\begin{array}{l}\text { Patients with } \\
\text { hypertension }\end{array}$ & 72 & FAPESP & $\begin{array}{l}15 \text { (78.9\%) } \\
\text { High Quality }\end{array}$ & 21 \\
\hline $\begin{array}{l}\text { Malfará M et al. } \\
(2018)^{25}\end{array}$ & São Paulo & $\begin{array}{l}\text { Retrospective } \\
\text { observational }\end{array}$ & 162 & $\begin{array}{l}\text { Patients admitted to the } \\
\text { Intensive Care Unit }\end{array}$ & 12 & None & $\begin{array}{l}9(47.4 \%) \\
\text { Low Quality }\end{array}$ & 14 \\
\hline $\begin{array}{l}\text { Aguiar KS et al. } \\
(2018)^{26}\end{array}$ & Paraná & $\begin{array}{l}\text { Retrospective } \\
\text { observational }\end{array}$ & NR & $\begin{array}{l}\text { Patients with } \\
\text { oncological and } \\
\text { hematological diseases }\end{array}$ & 1 & NR & $\begin{array}{l}7(36.8 \%) \\
\text { Low Quality }\end{array}$ & 15 \\
\hline $\begin{array}{l}\text { Oliveira CMX et } \\
\text { al. }(2016)^{27}\end{array}$ & São Paulo & Randomized & 119 & Patients with asthma & 20 & $\begin{array}{l}\text { CAPES } \\
\text { and } \\
\text { FAPESP }\end{array}$ & $\begin{array}{l}10(52.6 \%) \\
\text { Moderate } \\
\text { Quality }\end{array}$ & 18 \\
\hline $\begin{array}{l}\text { Obreli-Neto PR } \\
\text { et al. }(2015)^{21}\end{array}$ & São Paulo & Randomized & 200 & $\begin{array}{l}\text { Patients with diabetes } \\
\text { and hypertension }\end{array}$ & 36 & None & $\begin{array}{l}16(84.2 \%) \\
\text { High Quality }\end{array}$ & 18 \\
\hline $\begin{array}{l}\text { Carnevale RC et } \\
\text { al. }(2015)^{22}\end{array}$ & São Paulo & $\begin{array}{l}\text { Ambispective } \\
\text { controlled }\end{array}$ & 102 & Patients with HIV & 12 & $\begin{array}{l}\text { CAPES } \\
\text { and } \\
\text { FAPESP }\end{array}$ & $\begin{array}{l}13(68.4 \%) \\
\text { Moderate } \\
\text { Quality }\end{array}$ & 16 \\
\hline $\begin{array}{l}\text { Campos e } \\
\text { Reis HPL et al. } \\
(2013)^{28}\end{array}$ & Ceará & Case study & NR & $\begin{array}{l}\text { Patients treated by } \\
\text { a health insurance } \\
\text { company }\end{array}$ & 48 & NR & $\begin{array}{l}3 \text { (15.8\%) } \\
\text { Low Quality }\end{array}$ & 12 \\
\hline $\begin{array}{l}\text { Magedanz L et } \\
\text { al. }(2012)^{29}\end{array}$ & $\begin{array}{l}\text { Rio Grande } \\
\text { do Sul }\end{array}$ & Quasi-experimental & NR & $\begin{array}{l}\text { Patients in a cardiology } \\
\text { hospital }\end{array}$ & 73 & None & $\begin{array}{l}6 \text { (31.6\%) } \\
\text { Low Quality }\end{array}$ & 10 \\
\hline $\begin{array}{l}\text { Borges APS et } \\
\text { al. }(2011)^{30}\end{array}$ & São Paulo & $\begin{array}{l}\text { Retrospective } \\
\text { observational }\end{array}$ & 71 & $\begin{array}{l}\text { Patients with type } 2 \\
\text { diabetes mellitus }\end{array}$ & 12 & $\begin{array}{l}\text { CAPES } \\
\text { and } \\
\text { CNPq }\end{array}$ & $\begin{array}{l}9(47.4 \%) \\
\text { Low Quality }\end{array}$ & 15 \\
\hline
\end{tabular}

\section{Synthesis of the studies}

The study by Gonçalves et al. $(2019)^{23}$ evaluated the cost-effectiveness of a pharmacotherapeutic empowerment strategy in patients with type 2 diabetes mellitus by means of a non-randomized study in 12 months. The authors compared the pharmacist intervention $(n=46)$ with the standard treatment group $(n=30)$, evaluating the costs related to the health services and the intervention, in addition to the levels of glycated hemoglobin (A1c), used as an effectiveness parameter. It was observed that a reduction of 0.359 in A1c cost the intervention group US\$708.47 and that a reduction of 0.170 cost the control group US\$1,927.13. The ICER was US\$387.66 per patient/year, that is, the pharmacist practice represented significant savings for the health service.

Cazarim and Pereira (2018) ${ }^{24}$ conducted a cost-effectiveness analysis nested to a quasi-experimental study to evaluate the impact of PC in 104 patients with systemic arterial hypertension. The research compared the results of the intervention to the period before and after the pharmacist intervention. The direct and indirect medical costs, as well as blood pressure control, were considered for 6 years. The CERs in the pre-PC, PC and post-PC periods were US\$364.65, US\$415.39 and US\$231.14, respectively, resulting in an ICER of US\$478.41 in the PC period and of US\$42.95 in the subsequent period. The authors concluded that PC was a cost-effective measure in the treatment of patients with systemic arterial hypertension.

The study by Malfará et al. (2018), ${ }^{25}$ evaluated the number and types of interventions of the clinical pharmacist in a pediatric Intensive Care Unit and the reduction of the associated costs through a prospective observational study conducted over 12 months. Only the direct costs of purchasing the drugs were considered. Overall, 1,586 prescriptions were analyzed, of which
$12.4 \%$ presented problems related to pharmacotherapy. The pharmaceutical interventions generated savings of US\$4,828.00 for the health service and were mainly related to therapeutic monitoring and drug interactions, selection of therapy, posology, dose, prescription and administration.

The retrospective observational study conducted by Aguiar et al. $(2018)^{26}$ evaluated the pharmacist's role in reviewing prescriptions for antineoplastic and adjuvant drugs used in the treatment of patients with oncological and hematological diseases. In total, 6,104 prescriptions were evaluated; drug-related problems were identified in 274 (4.5\%). The pharmacist intervention in the interception of such problems generated savings of $R \$ 54,081.01$ (U\$9,688.89, exchange rate from 22 October 2020), with an expense of $R \$ 20,863.36$ ( $U \$ 3,738.66$, exchange rate from 22 October 2020), thus resulting in a positive balance of $R \$ 33,217.65$ (U\$5,952.52, exchange rate from 22 October 2020).

The randomized clinical trial conducted by Oliveira et al $(2016)^{27}$ evaluated the clinical and economic impacts of a self-managed asthma model promoted by a pharmacist. The outcomes included the assessment of knowledge on asthma, lifestyles, inhalation techniques, adherence to treatment, lung function and quality of life, as well as an economic feasibility analysis considering the direct costs. The intervention group $(n=60)$ obtained an increase in the knowledge on asthma, the number of individuals who practice physical exercises, the number of correct answers regarding the use of inhalers, the percentage of patients adhering to the treatment and the quality of life scores compared to the control group $(n=59)$. Finally, the intervention reduced drug costs by US\$1,128.24, emergency visit costs by US\$511.52 and hospital admission costs by US\$2,696.17. 
Table 2. Results of the economic evaluations of the studies included in the systematic review.

\begin{tabular}{|c|c|c|c|c|c|}
\hline Citation & Intervention & $\begin{array}{l}\text { Economic } \\
\text { evaluation } \\
\text { measure }\end{array}$ & Economic evaluation results & $\begin{array}{l}\text { Measure of clinical } \\
\text { outcomes }\end{array}$ & Results of the clinical outcomes \\
\hline $\begin{array}{l}\text { Gonçalves } \\
\text { ACO et al } \\
(2019)^{23}\end{array}$ & $\begin{array}{l}\text { Therapeutic } \\
\text { empowerment } \\
\text { strategy promoted } \\
\text { by a pharmacist }\end{array}$ & $\begin{array}{l}\text { CER and } \\
\text { ICER }\end{array}$ & $\begin{array}{l}\text { A reduction of } 0.359 \text { in A1c costs } \\
\text { US } \$ 708.47 \text { (intervention) and of } \\
0.170 \text { costs US\$1,927.13 (control). } \\
\text { ICER of US\$387.66 per patient/year. }\end{array}$ & A1c levels & $\begin{array}{l}\text { Considering } A 1 c \leq 7 \% \text { as controlled } \\
\text { patient, intervention group had } \\
\text { an increase (56.5\%), but with no } \\
\text { statistical difference. }\end{array}$ \\
\hline $\begin{array}{l}\text { Cazarim MS } \\
\text { and Pereira } \\
\text { LRL }(2018)^{24}\end{array}$ & $\begin{array}{l}\text { Pharmaceutical } \\
\text { care }\end{array}$ & $\begin{array}{l}\text { DC, IC, } \\
\text { CER, ICER }\end{array}$ & $\begin{array}{l}\text { Pre-PC, PC and post-PC periods } \\
\text { were of US\$364.65, US\$415.39 and } \\
\text { US\$231.14, respectively }\end{array}$ & Blood pressure control & $\begin{array}{l}\text { Treatments in the PC and post-PC } \\
\text { periods were more effective than } \\
\text { the conventional treatment in } \\
\text { controlling blood pressure. }\end{array}$ \\
\hline $\begin{array}{l}\text { Malfará M et } \\
\text { al }(2018)^{25}\end{array}$ & $\begin{array}{l}\text { Interventions } \\
\text { of the clinical } \\
\text { pharmacist }\end{array}$ & DC & $\begin{array}{l}\text { Total treatment costs were } \\
\$ 156,568.00 \text {. Pharmaceutical } \\
\text { interventions saved US\$4,828.00. }\end{array}$ & Drug-related problems & $\begin{array}{l}\text { Drug-related problems identified in } \\
12.4 \% \text { of the prescriptions. }\end{array}$ \\
\hline $\begin{array}{l}\text { Aguiar KS et } \\
\text { al }(2018)^{26}\end{array}$ & $\begin{array}{l}\text { Review of } \\
\text { prescriptions by a } \\
\text { pharmacist }\end{array}$ & DC & $\begin{array}{l}\text { Pharmaceutical intervention } \\
\text { generated savings of } \mathrm{R} \$ 33,217.65 \\
\text { (positive balance). }\end{array}$ & Drug-related problems & $\begin{array}{l}\text { Drug-related problems identified in } \\
274(4.5 \%) \text { of the prescriptions. }\end{array}$ \\
\hline $\begin{array}{l}\text { Oliveira CMX } \\
\text { et al }(2016)^{27}\end{array}$ & $\begin{array}{l}\text { Asthma } \\
\text { self-management } \\
\text { model promoted } \\
\text { by a pharmacist }\end{array}$ & $\mathrm{DC}$ & $\begin{array}{l}\text { Reduced drug costs were estimated } \\
\text { at US\$1,128.24, in addition to } \\
\text { savings related to emergency visits } \\
\text { (US\$511.54) and hospital admissions } \\
\text { (US\$2,696.17). }\end{array}$ & $\begin{array}{l}\text { Knowledge on asthma, } \\
\text { handling of the } \\
\text { inhaler, adherence to } \\
\text { therapy, lung function, } \\
\text { quality of life, patient } \\
\text { satisfaction }\end{array}$ & $\begin{array}{l}\text { Increase in knowledge on asthma, } \\
\text { number of individuals who practice } \\
\text { physical exercise, handling of } \\
\text { inhalers, percentage of adherence } \\
\text { to treatment and quality of life } \\
\text { scores }(p<0.001)\end{array}$ \\
\hline
\end{tabular}

$\begin{array}{lll}\text { Obreli-Neto } & \text { Pharmaceutical } & \text { DC and } \\ \text { PR et al } & \text { ICER per } \\ (2015)^{21} & \text { care } & \text { QALY }\end{array}$

Carnevale RC Pharmaceutical et al $(2015)^{22}$ care

Pharmaceutical

Campos and Reis HPL et al $(2013)^{28}$ audit in a health insurance company

Pharmacist intervention in Magedanz $L$ an antimicrobial et al $(2012)^{29}$ stewardship program
No statistical difference in direct costs (US\$281.97 \pm US\$49.73 per patient versus US\$212.28 \pm US\$43.49 per patient, respectively; $p=0.089)$. ICER per QALY was US\$53.50 (95\% Cl = US\$51.60-54.00)

For every US\$1.00 spent on PC, there was a loss of US\$1.42 per day. However, there was no statistical difference between the groups.

After 6 months, the pharmaceutical intervention in the use of

DC antimicrobials generated savings of $\mathrm{R} \$ 279,153.80$. Chemotherapy management resulted in a reduction of $R \$ 2,066,573.31$.

After the implementation of the program with the presence of the pharmacist, there was a significant reduction of $25 \%$ in the consumption of antimicrobials, and of $69 \%$ in the costs of hospital antibiotics.

PC significantly reduced costs with metformin and emergency department visits, but increased Borges APS Pharmaceutical DC primary care costs. The control group had an increase of $21.3 \%$ in the general costs of treatments and visits.
SBP, DBP, GI, A1C

evels, LDL cholesterol, Significant clinical improvements in 10-year risk of coronary heart disease

CD4+ count, viral load, absence of co-infections, ideal immune response. Number of drug-related problems all analyzed parameters $(p<0.05)$.

After 1 year, a higher percentage of better clinical outcomes was observed in the intervention group. Statistically significant reductions in drug-related problems $(p<0.001)$

\section{Length of treatment} with antimicrobial agents

There was a $66 \%$ reduction in the length of treatment with antimicrobial agents
Doses of antimicrobials The global consumption of consumed, expressed antimicrobials decreased from 48.9 in defined daily doses (mean of monthly consumption) (DDD) per 100 patient- during the first period to 36.9 in days the third period $(\mathrm{P}=0.001)$

Statistically significant reduction in A1c levels in patients in the PC group.

Note: A1c, glycated hemoglobin; PC, Pharmaceutical Care; DC, Direct Costs; IC, Indirect Costs; GI, Glycemic Index; NA, Not Applicable; DBP, Diastolic Blood Pressure; SBP, Systolic Blood Pressure; QALY, Quality-Adjusted Life-Year; CER, Cost-Effectiveness Ratio; ICER, Incremental Cost-Effectiveness Ratio.

Obreli-Neto et al. (2015) ${ }^{21}$ conducted a 36-month randomized clinical trial to investigate the economic impact of PC in elderly patients with diabetes and hypertension. The research groups were compared regarding the direct costs of the health services and the ICER per Quality-Adjusted Life-Year (QALY). There was no statistical difference between the intervention group $(n=100)$ and the control group $(n=100)$ in terms of total direct costs
(US\$281.97 \pm US\$49.73 per patient versus US\$212.28 \pm US\$43.4 per patient, respectively; $p=0.089)$. $P C$ resulted in incremental costs of US\$69.60 ( \pm US\$7.90) per patient. The ICER per QALY was US\$53.50 (95\% Cl = US\$51.60-54.00). However, in all clinical parameters analyzed, mainly related to disease markers, the pharmacist practice resulted in significant improvements compared to the control group $(p<0.001)$. 
The study by Carnevale et al. (2015), ${ }^{22}$ using an ambispective controlled design, was conducted to evaluate the clinical and economic effects of PC in HIV patients. The effectiveness measures included CD4+ cell count, viral load, absence of co-infections and ideal immune response, in addition to economic outcomes, which considered the direct costs of the health services after six months and one year. At six months, there was no statistical difference between the study groups ( $n=51$ in each group) regarding the clinical and economic parameters analyzed. However, after one year of study, the intervention group was able to significantly reduce the problems related to pharmacotherapy, although there was no statistically significant difference for the economic outcomes.

In a descriptive case study, Campos and Reis HPLetal. $(2013)^{28}$ reported the economic impacts of pharmaceutical auditing on a healthcare operator in the state of Ceará. The data, which were collected from 2007 to 2010, referred to the effect of the pharmacist intervention on the management of antimicrobials and chemotherapy. After six months, the pharmacist monitoring generated a reduction in the total consumption of antimicrobials and savings of R\$279,153.80 (U\$50,011.81, exchange rate from 22 October 2020). The management of chemotherapy by the health professional promoted savings of $R \$ 2,502,278.31$ (U\$448,295.79, exchange rate from 22 October 2020). to the health insurance company.

The quasi-experimental study by Magendanz et al. (2012) ${ }^{29}$ evaluated the role of the pharmacist in an antimicrobial stewardship program in a cardiology hospital. The analyses included data prior to the implementation of the program (stage 1), after the implementation with only an infectious disease physician (stage 2) and after the inclusion of the clinical pharmacist (stage 3). Comparing stages 1 and 3, there was a significant decrease of $25 \%$ in the consumption of antimicrobials, and of $69 \%$ in the costs of hospital antibiotics. The mean monthly antibiotic costs during stages 1,2 and 3 were US\$30,727.56, US\$18,034.89 and US\$9,623.73, respectively $(p<0.001)$. The authors conclude that the pharmacist played a key role in reducing costs with antimicrobials in this hospital.

Borges et al. $(2011)^{30}$ conducted an intervention study for 12 months to evaluate the costs related to medications and appointments in patients with type 2 diabetes mellitus monitored by a PC program. Although the intervention group $(n=40)$ showed an increase in the costs of primary care appointments, PC significantly decreased the costs with metformin and emergency department visits. The control group $(n=31)$, in turn, showed a statistically significant increase of $21.3 \%$ in the general costs of medications and appointments $(p<0.05)$.

\section{Methodological quality of the studies}

The scores obtained through the use of the CHEC-list tool are described in Table 1 and Figure 2. Of the 10 studies included in the review, the majority $(n=5)$ was classified as having low methodological quality; 2 studies presented moderate quality and 3 presented high quality. The methodological quality of the economic evaluations showed a mean score of 10.3 (range: 3-16 points) out of the instrument's 19 questions.

The questions with less adherence by the studies were as follows (Figure 2): appropriate economic study design for the objective (question 4); identification of all the relevant costs for each alternative (question 7); identification of all the relevant outcomes for each alternative (question 10); appropriate measurement of all the outcomes (question 11); appropriate valuation of all the outcomes (question 12); conduction of an incremental analysis of costs and outcomes of the alternatives (for example, without conducting an incremental cost-effectiveness analysis considering both costs and clinical outcomes; question 13); application of discounts for future costs and outcomes (question 14); conduction of a sensitivity analysis for relevant variables with uncertain values (question 15); discussion of the generalization of the results to other contexts or groups of patients (question 17); and appropriate discussion of ethical and distributional issues (question 19).

\section{Reporting quality of the studies}

The reporting quality of the studies varied considerably, with a mean score of 15.8 (range: 10-21 points) out of the 24 items of the CHEERS checklist, as shown in Table 1 and in Figure 3.

The items least contemplated by the publications were as follows (Figure 3): sufficiently detailed abstract (with no description, for example, of the perspective or time horizon; item 2); definition of the economic evaluation perspective (item 6); information about the discount rate used (item 9); description of the population and the methods used to measure preference for outcomes (item 12); data on currency, rate and currency conversion date (item 14); information on methods for characterizing uncertainties (item 20) and heterogeneity (item 21); and funding sources (particularly regarding the role of funders in conducting the research; item 23).

\section{Discussion}

This systematic review included 10 studies, which evaluated the economic impact of pharmacist interventions on Brazilian health services. The studies, conducted mainly in the Brazilian Southeast region, substantially differed in terms of design, economic outcomes models and type of intervention, which hindered comparative analysis of results. The individual evaluation of the economic studies indicated that most of them reported significant cost savings due to the pharmacist intervention, in addition to clinical improvements in terms of levels of disease markers and reduction of problems related to pharmacotherapy.

The innovations in health technologies and the high prevalence of incorrect or inappropriate use of medications contribute to a significant increase in costs, which highlights the need of the conduction of economic evaluation studies in health services. ${ }^{31,32}$ However, particularly in low- and middle-income countries, such as Brazil, the conduction of economic evaluations is challenging, due to the scarcity, low quality and lack of accessibility to data, the inherent limitations of health systems, the lack of government investments, and the funding restrictions for research in the field of health economics. ${ }^{33}$ In this scenario, pharmacists play an important role in the health services, due to their ability to reduce general health expenses, decrease unnecessary care, and reduce social costs. ${ }^{34}$

The results of this systematic review indicate that the pharmaceutical intervention can result in positive savings for the Brazilian health services. Gallagher et al. (2014) $)^{35}$ conducted a systematic review - including international economic evaluations from 2008 to 2012 - about pharmaceutical interventions in hospital settings and concluded that the pharmacists' work is economically beneficial, with reports of cost reductions in most of the research studies. According to the authors, significant savings were achieved mainly due to the prevention of adverse drug events. 
Figure 2. Percentage of the economic evaluations that correctly described the items on the CHEC-list checklist in their publications ( $n=10)$.

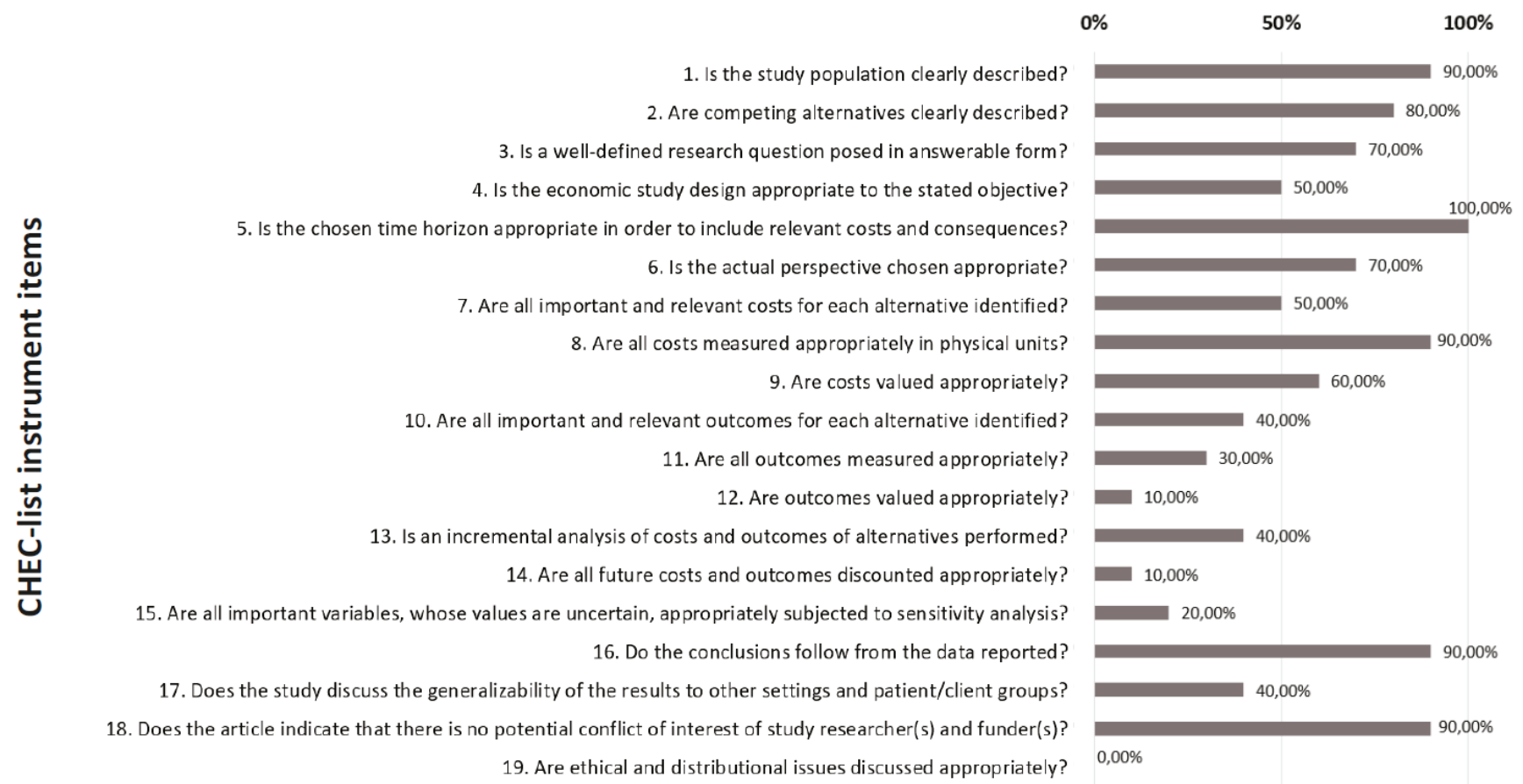

Figure 3. Percentage of the economic evaluations that correctly described the items on the CHEERS checklist in their publications ( $n=10$ ).

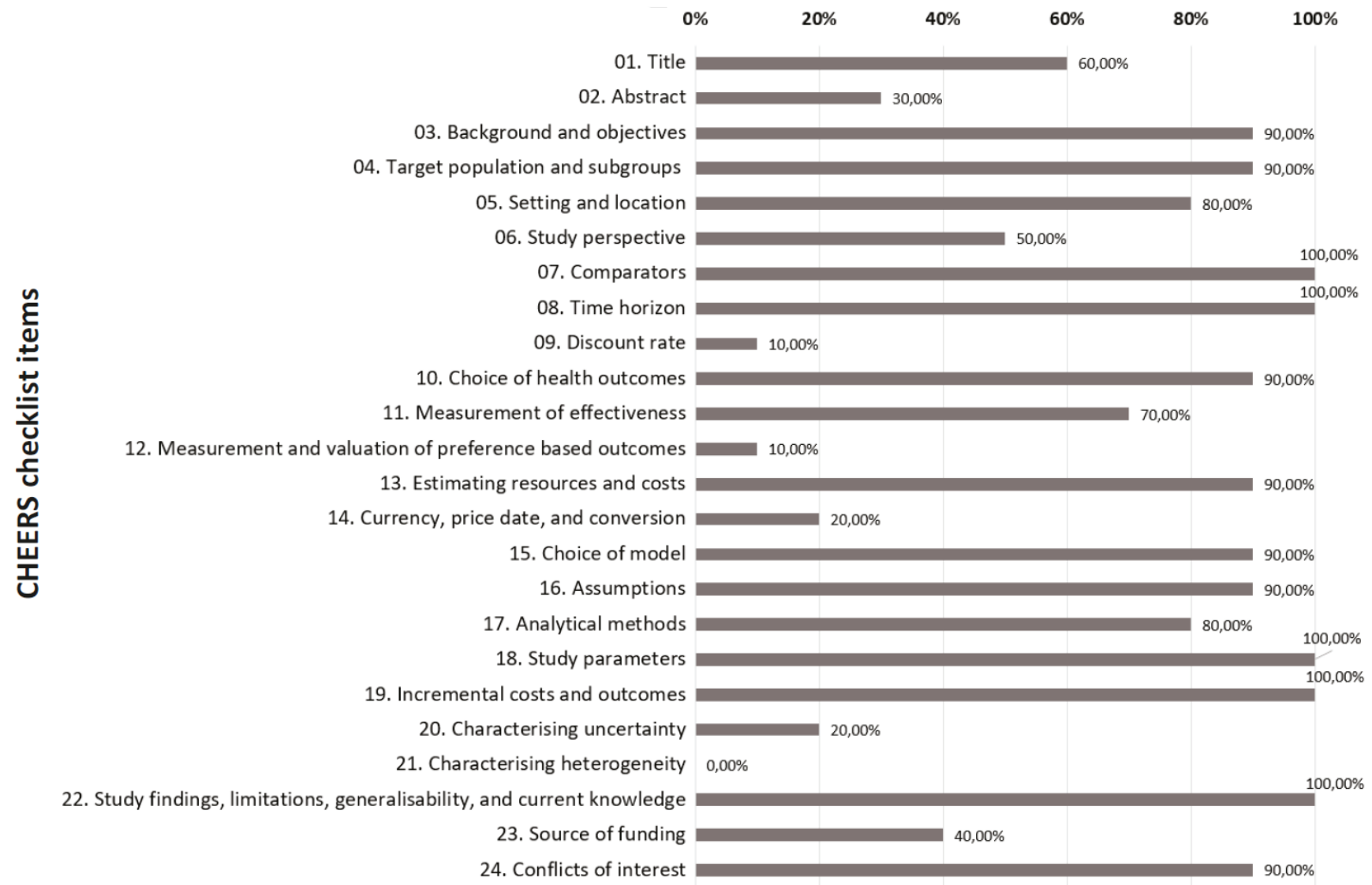


This study also reinforced the importance of the pharmacist in improving clinical parameters, such as reducing problems related to pharmacotherapy and improving levels of disease markers. In a previous systematic review, which investigated the benefits provided by the clinical pharmacist in pediatric hospitals, the pharmaceutical intervention resulted in a better understanding of the medication, greater adherence to treatment, greater patient satisfaction, and better control of chronic medical conditions. ${ }^{36}$ In a meta-analysis conducted with 42 studies, the intervention of the clinical pharmacist had a significant effect on lowering blood pressure and reducing hospitalization days. ${ }^{37}$

In general, the economic evaluations included in this review showed variable methodological quality. A previous systematic review, which included economic evaluations of pharmaceutical services in community pharmacies, also found a wide divergence in the quality and level of uncertainty in the studies. ${ }^{18}$ These findings can be explained by the high variability in study designs, the context of pharmaceutical services, the definition and measurement of comparators, the use of resources and the measurement of costs, in addition to the lack of standardization of outcome measures in economic evaluations of pharmaceutical interventions. ${ }^{38}$

Adherence to the criteria specified in the CHEERS checklist, which correlate with the reporting quality, was low in the studies included in the analysis. There was lack of reporting regarding relevant components for a high-quality economic analysis, such as detailing the methodology, measuring economic outcomes, uncertainties and heterogeneity, and describing the role of funding institutions in the conduction of the research. Previous researches that used this tool to investigate the quality of economic evaluations found similar results, with low compliance with the specifications. ${ }^{39-41}$ However, the study with the highest reporting quality included in this review concluded that pharmaceutical interventions had a positive impact and were cost-effective in a primary care service. ${ }^{24}$

This is the first systematic review to evaluate economic studies conducted specifically in Brazil on the role of the pharmacist, with analysis of the methodological and reporting qualities of the publications.

\section{Limitations}

This systematic review has some limitations. Despite the use of a systematic methodology, publication bias is possible, since studies that have not been published (due to negative results) or that are not indexed in the searched databases (gray literature) may not have been included. As previously discussed, the lack of standardization in the results of the researches and the low quality of the studies hampered the comparison of interventions. In the assessment of the reporting quality, it is possible that the scores were underestimated in studies in which some items were not applicable or that were published in other formats.

\section{Conclusion}

Most of the studies (80\%) conducted in Brazil have shown that pharmaceutical interventions result in cost savings for health services, in addition to improving clinical parameters related to the disease and to pharmacotherapy. The methodological and reporting qualities of these studies, however, are limiting factors; the economic evaluations, in general, showed low methodological quality and little adherence to the criteria recommended by the CHEERS checklist. Future high-quality studies are needed to highlight the economic and clinical importance of the pharmacist in Brazilian health services.

\section{Funding sources}

This research did not receive funding for its conduction.

\section{Collaborators}

Tiguman GB contributed to the design of the project, data analysis and interpretation, and writing of the article. Junior RM contributed to data analysis and interpretation and to the relevant critical review of the intellectual content. The authors approve the final version of the manuscript and are responsible for all the information presented in the paper, ensuring the accuracy and integrity of any of its parts.

\section{Conflict of interests statement}

The authors declare that there are no conflicts of interest regarding this article.

\section{References}

1. Sultana J, Cutroneo P, Trifiro G. Clinical and economic burden of adverse drug reactions. I Pharmacol Pharmacother. 2013;4(Suppl 1):S73-77.

2. Araujo PS, Costa EA, Guerra AAJ, et al. Pharmaceutical care in Brazil's primary health care. Rev Saude Publica. 2017;51(suppl 2):6s.

3. Reis WC, Scopel CT, Correr CJ, et al. Analysis of clinical pharmacist interventions in a tertiary teaching hospital in Brazil. Einstein (Sao Paulo). 2013;11(2):190-196.

4. Miranda TM, Petriccione S, Ferracini FT, et al. Interventions performed by the clinical pharmacist in the emergency department. Einstein (Sao Paulo). 2012;10(1):74-78.

5. Correr CJ, Otuki MF, Soler O. Assistência farmacêutica integrada ao processo de cuidado em saúde: gestão clínica do medicamento. Revista Pan-Amazônica de Saúde. 2011;2(3):41-49.

6. Sabater D, Fernandez-Llimos F, Parras M, et al. Types of pharmacist interventions in pharmacotherapy follow-up. Seguimiento Farmacoterapéutico. 2005;3(2):90-97.

7. Ambiel ISS, Mastroianni PC. Outcomes of pharmaceutical care in Brazil: a literature review. Rev Ciênc Farm Básica Apl. 2013;34(4):475-480.

8. Chisholm-Burns MA, Graff Zivin JS, Lee JK, et al. Economic effects of pharmacists on health outcomes in the United States: A systematic review. Am J Health Syst Pharm. 2010;67(19):1624-1634.

9. Giovanella L, Mendoza-Ruiz A, Pilar ACA, et al. Universal health system and universal health coverage: assumptions and strategies. Cien Saude Colet. 2018;23(6):1763-1776.

10. Doniec K, Dall'Alba R, King L. Austerity threatens universal health coverage in Brazil. Lancet. 2016;388(10047):867-868. 
11. Massuda A, Hone T, Leles FAG, et al. The Brazilian health system at crossroads: progress, crisis and resilience. BMJ Glob Health. 2018;3(4):e000829.

12. Watts J. Brazil's health system woes worsen in economic crisis. Lancet. 2016;387(10028):1603-1604

13. Morosini MV, Fonseca AF. Reviewing the Brazilian National Primary Healthcare Policy at such a time? Cad Saude Publica. 2017;33(1):e00206316.

14. Galvão TF, Pansani TdSA, Harrad D. Principais itens para relatar Revisões sistemáticas e Meta-análises: A recomendação PRISMA. Epidemiologia e Serviços de Saúde. 2015;24(2):335-342.

15. Wongpakaran R, Suansanae T, Tan-Khum T, et al. Impact of providing psychiatry specialty pharmacist intervention on reducing drug-related problems among children with autism spectrum disorder related to disruptive behavioural symptoms: A prospective randomized open-label study. J Clin Pharm Ther. 2017;42(3):329-336.

16. Evers $\mathrm{S}$, Goossens $\mathrm{M}$, de Vet $\mathrm{H}$, et al. Criteria list for assessment of methodological quality of economic evaluations: Consensus on Health Economic Criteria. Int J Technol Assess Health Care. $2005 ; 21(2): 240-245$.

17. Watts RD, Li IW. Use of Checklists in Reviews of Health Economic Evaluations, 2010 to 2018. Value Health. 2019;22(3):377-382.

18. Malet-Larrea A, Garcia-Cardenas V, Saez-Benito L, et al. Costeffectiveness of professional pharmacy services in community pharmacy: a systematic review. Expert Rev Pharmacoecon Outcomes Res. 2016;16(6):747-758.

19. Husereau D, Drummond M, Petrou S, et al. Consolidated Health Economic Evaluation Reporting Standards (CHEERS) statement. BMJ. 2013;346:f1049.

20. Husereau D, Drummond M, Petrou S, et al. Consolidated Health Economic Evaluation Reporting Standards (CHEERS)-explanation and elaboration: a report of the ISPOR Health Economic Evaluation Publication Guidelines Good Reporting Practices Task Force. Value Health. 2013;16(2):231-250.

21. Obreli-Neto PR, Marusic S, Guidoni CM, et al. Economic evaluation of a pharmaceutical care program for elderly diabetic and hypertensive patients in primary health care: a 36-month randomized controlled clinical trial. J Manag Care Spec Pharm. 2015;21(1):66-75.

22. Carnevale RC, de Godoi Rezende Costa Molino C, Visacri MB, et al. Cost analysis of pharmaceutical care provided to HIV-infected patients: an ambispective controlled study. Daru. 2015;23:13.

23. Goncalves ACO, Cazarim MS, Sanches C, et al. Costeffectiveness analysis of a pharmacotherapeutic empowerment strategy for patients with type 2 diabetes mellitus. BMJ Open Diabetes Res Care. 2019;7(1):e000647.

24. Cazarim MS, Pereira LRL. Cost-effectiveness analysis of pharmaceutical care for hypertensive patients from the perspective of the public health system in Brazil. PLoS One. 2018;13(3):e0193567.

25. Malfara M, Pernassi M, Aragon D, et al. Impact of the clinical pharmacist interventions on prevention of pharmacotherapy related problems in the paediatric intensive care unit. Int J Clin Pharm. 2018;40(3):513-519.
26. Aguiar KDS, Santos JMD, Cambrussi MC, et al. Patient safety and the value of pharmaceutical intervention in a cancer hospital. Einstein (Sao Paulo). 2018;16(1):eAO4122.

27. Olivera CM, Vianna EO, Bonizio RC, et al. Asthma selfmanagement model: randomized controlled trial. Health Educ Res. 2016;31(5):639-652.

28. Campos e Reis HPL, Nascimento MLdM, Ribeiro SRL, et al. Auditoria farmacêutica: estudo de caso em uma operadora de planos de saúde de Fortaleza (Brasil). Rev Ciênc Farm Básica Apl. 2013;34(2):215-221.

29. Magedanz L, Silliprandi EM, dos Santos RP. Impact of the pharmacist on a multidisciplinary team in an antimicrobial stewardship program: a quasi-experimental study. Int J Clin Pharm. 2012;34(2):290-294.

30. Borges AP, Guidoni CM, Freitas O, et al. Economic evaluation of outpatients with type 2 diabetes mellitus assisted by a pharmaceutical care service. Arq Bras Endocrinol Metabol. 2011;55(9):686-691.

31. AdemiZ, Kim H,ZomerE, etal. Overview of pharmacoeconomic modelling methods. Br J Clin Pharmacol. 2013;75(4):944-950.

32. Dalton K, Byrne S. Role of the pharmacist in reducing healthcare costs: current insights. Integr Pharm Res Pract. 2017;6:37-46

33. Pitt C, Vassall A, Teerawattananon $Y$, et al. Foreword: Health Economic Evaluations in Low- and Middle-income Countries: Methodological Issues and Challenges for Priority Setting. Health Econ. 2016;25 Suppl 1:1-5.

34. Murphy EM, Rodis JL, Mann HJ. Three ways to advocate for the economic value of the pharmacist in health care. J Am Pharm Assoc. 2020.

35. Gallagher J, McCarthy S, Byrne S. Economic evaluations of clinical pharmacist interventions on hospital inpatients: a systematic review of recent literature. Int J Clin Pharm. 2014;36(6):1101-1114.

36. Drovandi A, Robertson K, Tucker M, et al. A systematic review of clinical pharmacist interventions in paediatric hospital patients. Eur J Pediatr. 2018;177(8):1139-1148.

37. Lin G, Huang R, Zhang J, et al. Clinical and economic outcomes of hospital pharmaceutical care: a systematic review and meta-analysis. BMC health services research. 2020;20(1):487.

38. Elliott RA, Putman K, Davies J, et al. A review of the methodological challenges in assessing the cost effectiveness of pharmacist interventions. Pharmacoeconomics. 2014;32(12):1185-1199.

39. Aguiar PM, Lima TM, Storpirtis S. Systematic review of the economic evaluations of novel therapeutic agents in multiple myeloma: what is the reporting quality? J Clin Pharm Ther. 2016;41(2):189-197.

40. de Soarez PC, Silva AB, Randi BA, et al. Systematic review of health economic evaluation studies of dengue vaccines. Vaccine. 2019;37(17):2298-2310.

41. Arefian $\mathrm{H}$, Vogel $\mathrm{M}$, Kwetkat $\mathrm{A}$, et al. Economic Evaluation of Interventions for Prevention of Hospital Acquired Infections: A Systematic Review. PLoS One. 2016;11(1):e0146381 
Supplementary material $\mathbf{1}$. Search strategies in the databases, conducted on November 25th, 2019.

PubMed: ("Pharmacists"[Mesh] OR pharmaceutical care OR pharmacy OR pharmacist) AND (intervention OR impact OR contribution) AND (economic OR cost OR financial) AND (evaluation OR analysis OR study) AND (randomized controlled trial OR cohort OR case control OR observational OR cross-sectional) AND (brazil OR brazilian)

EMBASE: (pharmaceutical care OR pharmacy OR pharmacist) AND (intervention OR impact OR contribution) AND (economic OR cost OR financial) AND (evaluation OR analysis OR study) AND (randomized controlled trial OR cohort OR case control OR observational OR cross-sectional) AND (brazil OR brazilian)

LILACS: (pharmaceutical care OR pharmacy OR pharmacist) AND (intervention OR impact OR contribution) AND (economic OR cost OR financial) AND (brazil OR brazilian) 